\title{
P02.110. Effect of traditional acupuncture on circulating endothelial progenitor cells in patients with coronary heart disease
}

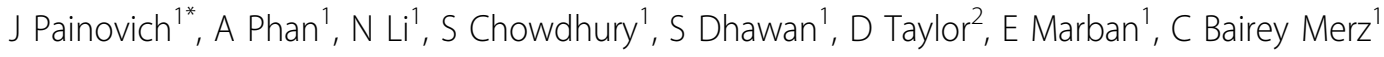 \\ From International Research Congress on Integrative Medicine and Health 2012 \\ Portland, Oregon, USA. 15-18 May 2012
}

\section{Purpose}

Endothelial progenitor cells (EPCs) are thought to exert beneficial effects on atherosclerosis, angiogenesis, and vascular repair. We performed a randomized pilot "proof of concept" study of traditional acupuncture (TA) and circulating EPCs in patients with coronary heart disease (CHD).

\section{Methods}

Thirteen subjects were randomized to TA, sham acupuncture (SA) or waiting control (WC) for 12 weeks. TA received treatments at $\mathrm{CHD}$ specific acupuncture points while SA received tube pressure with no needle insertion proximate to the TA site but not considered active. WC received no intervention. EPCs at study entry/exit were quantified by flow cytometry using CD34, CD133 and VEGFR2 cell surface markers.

\section{Results}

Eight men and five women (mean age $59 \pm 11$ yrs) were included. Compared to entry, TA had a significant increase in percentage change from baseline in level of cells expressing CD34+/VEGFR2+ compared to SA and WC $(\mathrm{p}=0.03)$. No group differences were evident in immature EPCs expressing CD34+/CD133+, although these were lowest in the TA group; numbers did not correlate with elevation in the CD34+/VEGFR2+group.

\section{Conclusion}

Results suggest that TA may increase mobilization of specific EPC sub-populations (VEGF R2) while simultaneously decreasing levels of a more immature cell type

${ }^{1}$ Cedars Sinai Medical Center, Los Angeles, USA

Full list of author information is available at the end of the article
(CD133) and may beneficially alter levels of EPCs. This pilot study provides feasibility and outcome variability data for clinical trial planning purposes. Further studies are warranted to evaluate whether traditional acupuncture can beneficially impact CHD via augmentation of EPC regenerative pathways.

\section{Author details \\ ${ }^{1}$ Cedars Sinai Medical Center, Los Angeles, USA. ${ }^{2}$ University of Minnesota,} Minneapolis, USA.

Published: 12 June 2012

doi:10.1186/1472-6882-12-S1-P167

Cite this article as: Painovich et al.: P02.110. Effect of traditional acupuncture on circulating endothelial progenitor cells in patients with coronary heart disease. BMC Complementary and Alternative Medicine 2012 12(Suppl 1):P167.

Submit your next manuscript to BioMed Central and take full advantage of:

- Convenient online submission

- Thorough peer review

- No space constraints or color figure charges

- Immediate publication on acceptance

- Inclusion in PubMed, CAS, Scopus and Google Scholar

- Research which is freely available for redistribution

\section{Ciomed Central}

